\title{
"Trade credit and bank credit as alternative governance structures in South Africa: evidence from banking sector development"
}

\begin{tabular}{ll} 
AUTHORS & Shame Mugova \\
\hline ARTICLE INFO & $\begin{array}{l}\text { Shame Mugova (2017). Trade credit and bank credit as alternative governance } \\
\text { structures in South Africa: evidence from banking sector development. Banks and } \\
\text { Bank Systems, 12(3), 204-214. doi:10.21511/bbs.12(3-1).2017.05 }\end{array}$ \\
\hline DOI & http://dx.doi.org/10.21511/bbs.12(3-1).2017.05 \\
\hline RELEASED ON & Monday, 09 October 2017 \\
\hline RECEIVED ON & Thursday, 22 June 2017 \\
\hline ACCEPTED ON & Wednesday, 09 August 2017 \\
\hline LICENSE & (cc) EY-Nc \\
\hline JOURNAL & This work is licensed under a Creative Commons Attribution-NonCommercial 4.0 \\
\hline ISSN PRINT & "Banks and Bank Systems" \\
\hline ISSN ONLINE & $1816-7403$ \\
\hline PUBLISHER & $1991-7074$ \\
\hline FOUNDER & LLC “Consulting Publishing Company "Business Perspectives" \\
\hline LLC “Consulting Publishing Company "Business Perspectives"
\end{tabular}

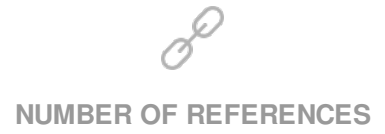

42

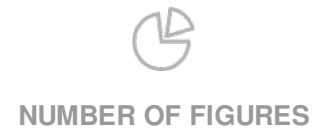

0
NUMBER OF TABLES

1

(C) The author(s) 2021. This publication is an open access article. 


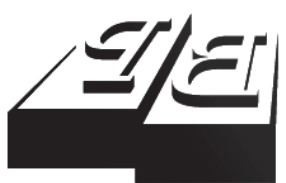

BUSINESS PERSPECTIVES

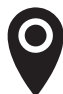

LLC "CPC "Business Perspectives" Hryhorii Skovoroda lane, 10, Sumy, 40022, Ukraine

www.businessperspectives.org

Received on: $22^{\text {nd }}$ of June, 2017 Accepted on: $9^{\text {th }}$ of August, 2017

(C) Shame Mugova, 2017

Shame Mugova, MBA, Department of Entrepreneurial Studies and Management, Durban University of Technology, South Africa.

\section{TRADE CREDIT AND BANK CREDIT AS ALTERNATIVE GOVERNANCE STRUCTURES IN SOUTH AFRICA: EVIDENCE FROM BANKING SECTOR DEVELOPMENT}

\begin{abstract}
Financial sector development is an influential force that outlines the financing and governance of firms in emerging economies. Suppliers and bankers represent alternative governance structures to a firm because of their trade credit and loan requirements, respectively. The continuous monitoring of investment by banks and suppliers impacts on corporate disclosure and practices. The study compares a sample of Johannesburg Stock Exchange (JSE) firms listed on the Socially Responsible Investment (SRI) index which measures corporate governance and those not listed on the index. A Generalized Least Squares (GLS) random effect regression of banking sector development and trade credit of firms listed on the JSE SRI and non-SRI listed firms was done to ascertain whether trade credit gives firms a preferred governance system and structure. The findings affirm that good corporate governance practices improve access to bank loans for working capital financing and good governance practices do not consequently result in more bank loan as a preferred governance structure for working capital financing compared to use of trade credit.
\end{abstract}

\section{Keywords}

JEL Classification corporate governance, trade credit, financial sector development, implicit cost.

\section{INTRODUCTION}

Corporate governance practices have a direct influence on both investment and access to capital. Banks and other investors evaluate the corporate governance structures of a firm before making an investment decision. It is also highly likely that poor corporate governance practices can result in failure to access bank credit, raise equity capital or result in issuing bonds with low market acceptance. Banks and creditors monitor and provide governance mechanism for firms. Bank loan and trade credit are alternative sources of working capital finance, the choice between the two is also a choice of preferred governance systems. Bank credit and short-debt such trade credit are both likely to constitute two significant corporate governance mechanisms (Florackis, 2008). It is conventional practice that creditors perform a dynamic role in the governance of firms even in cases where there is no payment default (Nini, Smith, \& Sufi, 2012). The role of creditors has largely been neglected as most analyses of corporate governance tend to focus on shareholders (Baird \& Rasmussen, 2006). 
Bondholders usually are limited in terms of what they can do until a firm default on a loan repayment. There are limitations in terms of bondholders, but it is not the same with bank loans or trade credit (Baird \& Rasmussen, 2006). It should be noted that bank monitoring plays a more important role for firms even when they have not defaulted on loan repayments. Bank and creditor monitoring has an effect of improving firm value (Shepherd, Tung, \& Yoon, 2008). Financial institutions carry out a monitoring function that is not usually available to firms without bank credit.

It is a difficulty for firms challenge governance ratings such as Governance Metrics International (GMI) considering the emphasis given to them by credit analysts and financiers (Sonnenfeld, 2004). Governance ratings greatly influence the creditworthiness of firms and their access to capital. Therefore, firms need to pay attention to their corporate governance systems in their choice of capital. Governance ratings may lack objective credibility despite this short coming they are widely used by providers of capital. Koehn and Ueng (2005) found that governance ratings are not perfect indicators of the superiority of firm's profits or of its ethics. However, Ashbaugh-Skaife, Collins, and LaFond (2006) found that corporate governance practices mostly exert influence on the cost of debt. Bank credit and trade credit are debt components which are therefore most likely to be affected by firm corporate governance. Familycontrolled firms have challenges in raising external capital, and fund most of their projects through internal capital (Shleifer \& Vishny, 1997). Corporate governance issues are some of the problems that result in small businesses to access bank credit. Shleifer and Vishny (1997) suggest that the principal reason of designing a corporate governance system is to introduce significant assurance which enables development of extensive outside financing. Reduced cost of equity is usually a result of better governance which reduces agency and information risks (Ashbaugh-Skaife et al., 2006).

Financiers have a fundamental role in the corporate governance firms to ensure that their funds are not used improperly. Bank credit contracts outlines the use of funds, and how the returns are shared between the firm and the bank (Shleifer \& Vishny, 1997). Whilst banks require stringent corporate governance mechanism, on the one hand, creditors through trade credit arrangements have the advantage that it is not possible to divert inputs easily compared to cash. Banks require financial statements from firms when assessing ability to repay loans and monitoring loans whilst shareholders also rely on the financial reporting. Suppliers, on the other hand, monitor the creditworthiness of their customers by monitoring how quickly they settle their arrears. Sharma (2014) notes that disclosure through financial statements enables investors to deal with operational risk by ensuring a framework of transparency. Disclosure is a fundamental link of corporate governance and financial reporting. There is also a link between financial reporting and financial markets. Debt and equity should not only be treated as substitute financing sources, but also as alternative governance systems (Williamson, 1988).

Trade credit research has exposed that suppliers have superior advantage over banks, i.e., they have better control and have more information about their trading partners and can discontinue supply of goods. The supplier has an edge over financial institutions such as banks in inspecting the creditworthiness of their clients, as well as an enhanced capability to provide ongoing monitoring and enforce repayment (Petersen \& Rajan, 1997). The choice to finance with either trade credit or bank loan may therefore be also a choice whether a company meets the bank corporate governance requirements or the supplier's and not necessarily which mode of financing is cheaper. If a company meets the corporate governance requirements of both banks and suppliers, they may have to choose between the two which is the preferred governance structure.

Kwenda and Holden (2013) advocate that if resources are efficiently used in a sustainable manner, firms ought to finance with the cheapest source between trade credit and bank loan. Firms listed on the Johannesburg Stock Exchange (JSE) use trade credit and bank credit. Ng, Smith, and Smith (1999) concluded that the implicit interest on trade credit is high compared to bank loan interest. Petersen and Rajan (1997) also reached a related deduction that accounts payables are a costly substitute for bank 
credit. Y. Ge and Qiu (2007) state that in countries with a poorly developed financial sectors, firms can sustain their expansion through trade payables. Fisman and Love (2003) found that businesses that use more trade credit grow comparatively faster in economies with poorly developed financial markets. South Africa is an emerging economy with one of the most well-developed and advanced capital markets in Africa. South Africa is a member of the BRICS and its banking system compares fairly to the financial sectors of more advanced economies (Skerritt, 2009).

Kwenda and Holden (2013) found that nearly half of current assets amongst listed companies in South Africa are financed by trade credit. Regardless of the financial sector development in South Africa firms rely on trade credit as a source of financing working capital despite its high implicit costs (Mugova \& Sachs, 2017). Financial development is defined by Graff (2003) as a function of growth in size, the quality and how well financial intermediaries perform their role. Literature identifies financial sector development as a necessary aspect important for a country to achieve economic growth. Chen, Chen, and Wei (2009) postulates that corporate governance influences the cost of equity. Good corporate governance has an effect of reducing the cost of equity. The corporate governance effect is more evident in emerging economies. The impact of corporate governance on cost of equity was more noticeable in countries that has poor legal systems (Chen et al., 2009).

In well-developed economies, financing is commonly combined with the supply of goods in the form of accounts payables (Demirgüç-Kunt \& Maksimovic, 2001). Rajan and Zingales (1995) offered confirmation that $18 \%$ of the total assets of US firms in 1991 comprised of trade receivables. Lee and Stowe (1993) computed the amount of trade credit in 1985 in United States and found that it exceeded bank lending. The fact that trade credit is widely used in countries with highly developed financial sectors such as United States and United Kingdom implies that there are some factors which influence the choice of trade credit.

Creditor governance is generally ignored in the legal and capital choice literature (Shepherd et al., 2008). Previous literature has not extensively explored the choice and influence between firm corporate governance and financial sector development. This paper focuses on bank loan and trade credit, and investigates the choice between these two sources in the context of financial sector development and corporate governance practices. Whereas banks require a certain level of corporate governance, suppliers also considers how a firm is governed to advance trade finance. Previous literature does not consider trade credit and bank credit choice as influenced by corporate governance. Corporate governance is an important factor which affects firm's access to capital. $\mathrm{Du}, \mathrm{Lu}$, and Tao (2012) found that in China, firms can support their growth through trade credit, because the country's financial sector is poorly developed (see also Y. Ge and Qiu (2007). Wu, Lin, and Wu (2014) investigated the influence of social responsibility on the cost of capital and deduced that socially responsible firms access capital at a lower cost. B. Cheng, Ioannou, and Serafeim (2014) investigated whether superior social responsibility leads to better access to capital and found that companies with superior social responsibility practices and systems face reduced capital constraints. Social responsibility can have a favorable influence by granting firms with superior access to capital (Cochran \& Wood, 1984; Waddock \& Graves, 1997). The presence of Socially Responsible Investment (SRI) index at the Johannesburg Stock Exchange which rates firms that are socially responsible and have good corporate governance gives an exclusive prospect to investigate the influence of corporate governance on a firm's choice of trade credit over bank loans. The preference of trade credit over bank credit is also an interesting phenomenon in the light of banking sector development.

The rest of the paper is organized as follows; section 1 reviews the literature on trade credit and bank credit discourse and analyzes them in the context of alternative governance systems. Section 2 presents the description of data sources and the sample used. Section 3 presents findings and discussion and the conclusions drawn are presented in last section. 


\section{LITERATURE REVIEW}

Fisman and Love (2003) found that companies operating in economies with poorly developed financial sectors substitute bank credit with trade credit. Bank loans and trade credit are used as complements or substitutes in financing working capital (Burkart \& Ellingsen, 2004). It can be argued that access to bank credit due to financial sector development gives ability to firms to reduce costly trade credit. Corporate governance influences access to external finance. There are companies whose access to capital may be restricted by inability to meet the bank credit corporate governance requirements. Cunat (2007) claims that some firms may finance their operations with trade payables when other sources of finance are not accessible. Trade credit is a crucial source of finance for companies with capital constraints such as limited access to bank credit (N. S. Cheng \& Pike, 2003). It is usually quick and easy to obtain finance from suppliers through trade credit than to obtain bank credit. If firms have limited access to financial institutions, they resort to trade payables as an alternative.

Corporate governance entails the systems and procedures by which suppliers of capital assure themselves of getting a return on their investment. Banks and suppliers are exposed to default risks when they provide capital. Ferrando and Mulier (2012) found supportive evidence of the argument that trade credit is an alternative source for financing production. Banks use collateral whilst suppliers use their relationship, their ability to seize supplied goods and discontinue supplies. The major reason why investors provide external financing is that they receive control rights in exchange (Shleifer \& Vishny, 1997). It should be further emphasized that investors need legal protection of their investment when they provide capital (Shleifer \& Vishny, 1997).

Banks and creditors monitor and provide governance mechanism for firms. Bank credit and trade credit provide alternative governance structures for firms. The choice between the two substitutes of financing working capital may therefore be a choice of governance systems. Today's creditors craft detailed contracts that offers them an enormous role in the governance of firms they finance
(Baird \& Rasmussen, 2006). Financial development, predominantly when aspects such as capital market regulation and efficiency are concerned has an effect of forcing firms to improve their corporate governance systems and structures. Corporate governance systems are important to improve firm's access to funding. A study by Ashbaugh-Skaife et al. (2006) provides indication that corporate governance is likely to influence the price of debt. Banks charge favorable interest rates and offer larger loans with long-term maturity, and impose less restrictive contracts to firms with good corporate governance (W. Ge, Kim, \& Song, 2012).

Bankers act as agents and usually strictly require high level of good corporate governance than what is normaly required by trading partners. If trading partners are less strict on corporate governance standards firms may choose trade credit instead of bank credit if they are not able to meet the demands of bankers. A firm's inability to acquire bank credit due to inferior corporate governance systems may force them to resort to financing working capital through trade credit. The borrower is normally required to maintain a consistent supply of information to the bank, detailing the business' performance and financial condition (Shepherd et al., 2008). When a business fails to pay its obligations, creditors normally have powers that shareholders never possess, such as ability to replace the managers and install those they prefer (Baird \& Rasmussen, 2006). The influence of creditors in the affairs of a corporation represents a governance mechanism which is usually not enjoyed by other investors. Creditors have the autonomy to exercise their powers even when the firm is not yet insolvent (Baird \& Rasmussen, 2006). Banks monitor their borrowers through the banking relationship whilst creditors can monitor their borrowers through the normal course of business, the later enjoy monitoring advantages over financial institutions. A bank normally obliges its borrower to maintain its deposit accounts with the bank, a scenario that allows the bank to monitor its borrower's cash flow (Shepherd et al., 2008).

Firms with bank credit should be viewed as better governed than their counterparts who fail to access bank credit. The publication of a bank credit arrangement sends positive news to the financial 
markets about the quality and creditworthiness of the firm (Florackis, 2008). Firms with superior access to bank credit can balance stakeholder's interests including those of investors. The bank's resolution to give credit to a firm act as a signal for better governed firms (Shepherd et al., 2008). The bank acquires private information about the firm during its due diligence process before granting a loan. Its lending decision may therefore express favorable private information concerning the firm's prospects and ability to repay its obligations (Shepherd et al., 2008). Byers, Fields, and Fraser (2008) found that loan announcements have prospects of making positive wealth effects for companies with weak internal corporate governance. Despite the benefits of financing through bank credit, firms nevertheless finance part of their working capital through trade credit. Nilsen (1999) found that trade credit, is unattractive alternative for bank loans because it is combined with the purchase of goods and has high implicit cost.

Managers usually take a defensive position about their strategies and become inflexible in the ways they do business. Bank monitoring can help lessen the firm value lost because of managerial entrenchment (Shepherd et al., 2008). Bank monitoring is a governance mechanism that helps improve financial discipline. It is very important when entrenchment would encourage managers to spend free cash (Shepherd et al., 2008). Banks view the firm's internal corporate governance systems and structures as an important factor that mitigates agency and information risk. W. Ge et al. (2012) found that legal institutions within an economy and firm-level governance mechanisms help each other in influencing bank credit agreements.

Bank monitoring has extensive influence on the governance of firms and it also affects the performance of firms generally. The bank's loan contract ensures ongoing monitoring to prevent managerial slack. If managerial slack is detected, the bank may either exit or intervene, even by changing management (Shepherd et al., 2008). The comprehensive financial reporting requirements and covenants enforced by the loan arrangement, as well as the bank's capability to control the borrower's bank account, empowers the bank to literally to control the firm (Shepherd et al., 2008). Banks normally demand management changes when a firm fails to repay its loan obligations (Shepherd et al., 2008).

Favorable agreements require the borrowing firm to take measures such as complying with generally accepted accounting principles and timely submission of financial reports to the bank. The firm must meet all regulatory reporting requirements, tax returns, maintaining equipment, purchasing insurance and being compliant with the law (Nini et al., 2012). The control rights granted to creditors following a contract violation serve a corporate governance function that assists firms to increase their value (Nini et al., 2012). Bank loans come with detailed agreements covering a lot of aspects such as minimum cash receipts and timely supply of audited financial accounts. When a firm fails to meet one of the covenants in a large loan, the bank is able to exercise de facto control rights such as changing the CEO. Shareholders of public companies do not normally have powers to change the CEO (Baird \& Rasmussen, 2006).

There are legal and institutional mechanisms that assist to direct the efforts of the lender toward containing and correcting managerial slack and have impact on firm level corporate governance (Triantis \& Daniels, 1995). Research reveals the critical importance of banks in financing industrial growth and the corporate governance of firms (Levine, 2004). If the corporation breaks the loan agreements or defaults on the payments, then banks usually acquire the rights to repossess collateral. The actions of bankers can throw the business into bankruptcy proceedings, they also vote in the decision to reorganize or remove managers (Levine, 2004)

Bank debt also bears important renegotiation characteristics unlike trade credit. The breaking of an agreement is considered as an event of failure to pay, giving the bank the right to demand immediate repayment, or accelerate, the entire loan balance (Nini et al., 2012). Banks do not usually accelerate the loan repayment, opting rather to use the acceleration right to initiate a renegotiation of the loan agreement. These renegotiations can result in changes of the terms of the initial loan and increased monitoring by banks (Nini et al., 2012). A bank's willingness to renew a loan facility point out the presence of a good relationship 
between the borrowing firm and the bank. This ability to renew loan facilities with bankers is a good signal about the quality of the firm. The loan agreement changes for defaulting firms result in amended credit contracts that are more strict and exert informal influence on corporate governance (Nini et al., 2012).

It is likely to be difficult to acquire bank unsecured credit whilst it is relatively easy to obtain trade credit because the supplier has more constant interaction with trading partners and is more informed of the customers' creditworthiness compared to financial institutions (N. S. Cheng \& Pike, 2003). Monitoring costs of trade credit are lower for suppliers than the monitoring costs of a bank unsecured loan. The supplier may visit and interact with trading partners more often compared to banks. The quantitates and how often the buyer orders give an indication of the financial condition of the buyer (Petersen \& Rajan, 1997).

Trade credit also gives the advantage to suppliers of controlling the governance and operations of the buying firm. If the products supplied few alternative suppliers, then the supplier can threaten to stop supplies. A common justification for using trade credit by suppliers is that they enjoy monitoring advantages over financial institutions (Burkart \& Ellingsen, 2004). The supplier may have an advantage over banks in investigating the creditworthiness of clients and better ability to monitor and force repayment (Petersen \& Rajan, 1997). It is normally less profitable for a borrower to divert goods supplied than to divert cash (Burkart \& Ellingsen, 2004).

A customer can face several late payment penalties such as high implicit cost and the potential of damaging long-term important business relationships (Petersen \& Rajan, 1994). The buying of goods through trade credit may prove to be expensive especially where discounts are foregone. The supplier can stop the supply of important goods necessary for operations or production in case of failure to pay on time (Cunat, 2007). In emerging economies, trade credit is viewed less favourably, because it is often a result of arrears and cash flow constraints (Bonin \& Wachtel, 2003). The sudden loss of supplies can result in more problems such as unfulfilled orders and damaging of reputation of the company that defaults. The supplier can also repossess the goods which may result in interruption of production processes. Trade credit must be settled when the credit period ends whilst bank loans can be re-negotiated and rolled over. The failure to pay trade credit obligations may result in serious immediate consequences compared to bank loans.

Trade credit is limited because it is only available as part of goods purchased unlike bank credit which can be used for purchasing other goods. The finance motive of using trade credit imply that it is considerably an unattractive alternative source of capital for bank loans because it is combined with the purchase of goods, while loans are in the form of cash (Nilsen, 1999). Trade credit can therefore not be diverted to fund critical areas which may be lacking resources because it is inflexible compared to bank credit.

\section{Research question}

Does good corporate governance practice result in improved access to bank finance which consequently results in substituting high cost trade credit with lower cost bank loans in working capital financing?

\section{METHODOLOGY AND DATA SOURCES}

South Africa is one of the emerging economies with a well-developed financial sector, but a study by Kwenda and Holden (2013) on the Johannesburg Stock Exchange listed companies in South Africa reveals that they employ considerable amounts of trade credit as a source of short-term finance. The comparison of Socially Responsible Investment (SRI) index constituent firms and firms who are non-constituents of the SRI gives a unique test of the relationship between use of trade credit and good corporate governance. Financial sector development proxies for South Africa's economy are used and corporate governance as measured by SRI index is the factor affecting an individual firm's access to capital and the dependent variable is trade credit. The period of study is 2015-2016 because the SRI index is reviewed yearly and some firms are added and dropped from the index. 


\subsection{SRI index}

The JSE launched the SRI Index in South Africa in May 2004 to identify those companies listed on the JSE that integrate the principles of the triple bottom line and good governance into their business activities. The Index philosophy is founded on the principles of the three pillars of the triple bottom line, namely environmental, social and economic sustainability, with good corporate governance underpinning each. Corporate governance provides the rules by which a company governs its business and the processes they have in place to enforce these rules and make sure that they are being applied in their dealings with all stakeholders. Therefore, the sustainability index in South Africa for JSE listed firms can be adopted as a measure of good corporate governance as well. The requirements for listing on the JSE SRI index also comprise of good governance principles.

Companies listed on the Johannesburg Stock Exchange Socially Responsible Investment Index and those not listed on the Socially Responsible Investment (SRI) index were selected. The study investigates whether their use of trade credit is influenced by their corporate governance practices. A sample of 63 non-financial SRI index companies were chosen out of a total population of 69 SRI index firms as of 30 September 2016. A sample of and 63 non-listed SRI firms was also chosen to compare trade credit use. The SRI index is used as a measure of corporate governance. Financial institutions were deliberately left out of the samples, mainly because they provide finance to non-financial firms and their impact is reflected in the financial sector development variables. The concept of working capital does not apply to banks since financial institutions do not have typical current assets and liabilities such as inventories and accounts payable. Published financial statements of the firms downloaded from Bloomberg provided data for trade payables and total current liabilities from annual statements of financial position for the year ending 2016. The ratio of trade payables to total current liabilities was calculated to get the percentage of working capital financed by trade payables referred to as trade credit. Financial development sector proxies were taken from the World Bank's Global Development Financial Database and 2016 figures were used. A pairwise correlation was done to investigate whether there is a relationship between trade credit use and banking sector development. A Generalized Least Squares (GLS) random effect regression analysis was carried out after a Hausman test was carried out to choose between fixed effect and random effect. In a random effects model, the unobserved variables are assumed to be uncorrelated with all the observed variables. Financial sector variables were the independent variables and the trade credit (trade payables/total current liabilities) being the dependent variable. If differences across entities have some influence on the dependent variable of trade credit the random effects model is appropriate. Random effects assume the individual specific effects are uncorrelated with the independent variables.

A regression analysis was carried out with banking sector variables being independent variables. The specification test of the regression model is the Hausman test for endogeneity (Hill, Griffiths, \& Lim, 2008). The choice of fixed or random effects was based on Hausman test results. The null hypothesis is that the preferred model is random effects rather than the fixed effects (Torres-Reyna, 2007). Hausman's specification test is employed to test hypotheses in terms of bias or inconsistency of an estimator. A Hausman test is usually used to determine the reliability of the Generalized Least Squares estimator (Ahn \& Low, 1996). The Hausman test has good command of identifying endogenous regressors (Ahn \& Low, 1996). A structural equation of trade credit is formulated that contains an explanatory variables of banking sector development which are endogenous. The choice of the strictly exogenous regressors is an investigated hypothesis. A Hausman test is based upon the difference between the fixed effects and the Hausman and Taylor estimators (Baltagi, Bresson, \& Pirotte, 2003).

\section{FINDINGS AND DISCUSSION}

\subsection{Hausman test}

Hausman's test is applicable in the choice of fixed or random effects. The reason why random effects model is applied is that the differences across entities are expected to be random and uncorrelated with the banking development variables used in 
the model. The justification for using a random effects model is that, unlike the fixed effects model, the differences across firms are assumed to be random and uncorrelated with the predictor variables included in the model (Mugova \& Sachs, 2017). If the differences across firms have some influence on trade credit choice, the random effects are appropriate. The independent variables are bank deposits to GDP, bank concentration which are all measures of banking sector development.

The Hausman test was conducted to select between fixed effects and random effects. The null hypothesis is that random effect model is applicable. The obtained result of $p=0.0690$ leads to acceptance of the null hypothesis and to conclude random effect model is appropriate.

Table 1. Hausman test results

\begin{tabular}{l|c:c|c}
\hline \multirow{2}{*}{ Variable } & \multicolumn{3}{|c}{ Coefficient } \\
\cline { 2 - 4 } & re & fe & difference \\
\hline $\mathrm{BD} / \mathrm{GDP}$ & -0.0058 & -0.0051 & 0.0000 \\
$\mathrm{BC}$ & -0.0006 & -0.0006 & 0.0000 \\
& \multicolumn{3}{c}{ Prob $>$ chi $2=0.0690$} \\
\hline
\end{tabular}

The average of

$$
\frac{\text { trade payables }}{\text { current liabilities }}
$$

for sample firms not listed on SRI was $69 \%$ and for SRI sample constituents was $67 \%$ for the period 2015 to 2016. There is no difference between the two groups of firms both heavily rely on trade payables to finance their current liabilities. The differences in corporate governance practices do not necessarily result in differences in using trade credit as a mode of financing. SRI constituent firms have better access to bank loans than their counterparts despite that they also heavily finance their working capital with trade credit.

\subsection{Non-SRI listed firms}

A pairwise correlation was computed to test whether there is a relationship between trade credit use and banking sector development. Bank concentration gave a result $\mathrm{p}=0.0457>0.01$. Based on this result, we reject the null hypothesis that there is a relationship between trade credit and bank concentration. Bank deposits to GDP gave a result $p=0.0764>0.01$. Based on this we reject the null hypothesis that there is a relationship between trade credit use and bank deposits to GDP. Through the Chi-square test $\mathrm{P}=0.1940>0.01$, we accept the null and reject the alternative hypothesis, which means the model is statistically insignificant at $99 \%$ level of confidence, the model does not have explanatory power of the dependent variable trade credit, the financial sector (bank concentration, bank deposits/GDP) are not determinants of trade credit demand, respectively. For the $\mathrm{t}$ test for our coefficients, bank concentration is $\mathrm{p}=$ $0.0457>0.05$. Based on this we accept the null hypothesis which means bank concentration has no significant impact on trade credit. Bank deposits to GDP is $p=0.0764>0.05$. Based on this we accept the null hypothesis and conclude that bank deposits to GDP does not influence trade credit use. We are confident at 95\% level that the bank sector development (bank deposits to GDP and bank concentration) equals zero and has no significant effect on trade credit.

\subsection{SRI listed firms}

A pairwise correlation was computed to test whether there is a relationship between trade credit use and banking sector development. Bank concentration gives the result $\mathrm{p}=-0.0806<0.01$. Based on this we accept the null hypothesis that there is a relationship between trade credit and bank concentration. Bank deposits to GDP gives the result $p=-0.0141<0.01$. Based on this we accept the null hypothesis that there is a relationship between trade credit use and bank deposits to GDP. Through the Chi-square test $\mathrm{P}=0.0004<0.01$, we reject the null and accept the alternative hypothesis, which means the model is statistically significant at $99 \%$ level of confidence, the model does have explanatory power of the dependent variable trade credit, the financial sector (bank concentration, bank deposits/GDP) are determinants of trade credit demand, respectively. For the $\mathrm{t}$ test for our coefficients, bank concentration is $\mathrm{p}=$ $-0.0806<0.01$. Based on this we reject the null hypothesis which means bank concentration has a significant impact on trade credit use by SRI listed firms. Bank deposits to GDP gives the result $\mathrm{p}=-$ $0.0141<0.01$. Based on this we accept the null hy- 
pothesis and conclude that bank deposits to GDP does influence trade credit use. We are confident at $99 \%$ confidence level that the bank sector development (bank deposits to GDP and bank concertation) does not equal zero and has a significant effect on trade credit use.

The findings from the research reveal that, contrary to expectation, firms do not ordinarily avoid the expensive trade credit to finance their working capital needs despite financial sector development. Trade credit financing amongst SRI index listed firms confirms the financial sector (bank concentration, bank deposits/GDP) are determinants of trade credit demand. Therefore, corporate governance practices influence firms' access to capital.
The levels of corporate governance do not necessarily result in firms reducing financing costs by switching from expensive trade credit to cheaper bank loans. SRI index listed firms gain more reputation and trust and they continue to receive trade credit from their trade counterparts. Firms not listed on the SRI index showed no relationship between financial sector development and their use of trade credit. The possible explanation here is that they have less access to bank credit compared to SRI listed firms. The possible way for non-SRI index listed firms to improve their access to bank loans is through improving their corporate governance practices. Good corporate governance practices enable firms to benefit from changes in financial sector development.

\section{CONCLUSION}

The decision of firms to use trade credit is not subject to the level of financial sector development. This paper concludes that trade credit is a critical source of capital even in well-developed financial markets confirming the findings of Kwenda and Holden (2014). Use of more trade credit by listed firms with good corporate governance practices reflected by SRI index listing means that increased access to bank capital does not consequently result in reduced use of trade credit.

A relationship between trade credit use and banking sector development amongst firms listed on the SRI index is established and no relationship between trade credit use and banking sector development amongst firms not listed on the SRI index. The findings affirm that good corporate governance practices improve access to bank loans for working capital financing, but good governance practices will not consequently result in more bank loan use than trade credit. Trade credit is a preferred governance structure compared to bank credit in financing working capital. Bank credit as a governance structure has more complicated requirements compared to trade credit which happen in the normal transacting course of business and is relatively easy to negotiate.

The findings of this present study are limited by the use of Socially Responsible Investment index which is not strong enough evidence to establish the role corporate governance in access to capital. The Socially Responsible Investment index reflects general attitude of the companies towards socially important issues and is not an absolute measure of corporate governance. The firm's business risk, cash flow, profitability and financial leverage is more important in making financing decision. The preference of trade credit or bank loan as an external source is likely to be influenced by business relationships and track record with bankers. The use of bank loans is largely influenced by either increasing leverage or reducing leverage in order to maintain the target capital structure. Corporate governance as a quality factor of credit risk assessment helps ascertain the ability of firms to repay loans by balancing the interest of all stakeholders including financiers and suppliers in credit relationships.

Corporate governance practices determine firm's access capital. Regardless of the level of financial sector development in an economy firm access to capital will vary. Good corporate governance systems and practices have an outcome of improved access to bank credit but do not result in substituting high cost trade credit with bank loans in financing working capital. The probable justification for continued use of trade credit maybe market power whereby large firms demand trade credit from their trading coun- 
terparts and mutual relationships between trading partners. The influence of corporate governance in relationships with trading partners which promotes trade credit will profit from further inquiry. This paper was only dedicated to trade payables as a source of working capital and did not consider receivables as an investment in trade credit. The continuous use of trade credit regardless of its high implicit costs also warrants further investigation. Such investigation should focus on ascertaining whether there are other aspects which can help to determine the choice of capital apart from the good corporate governance and good relationships with suppliers.

\section{REFERENCES}

1. Ahn, S. C., \& Low, S. (1996). A reformulation of the Hausman test for regression models with pooled cross-section-time-series data. Journal of Econometrics, 71(1), 309-319.

2. Ashbaugh-Skaife, H., Collins, D. W., \& LaFond, R. (2006). The effects of corporate governance on firms' credit ratings. Journal of accounting and economics, 42(1), 203-243.

3. Baird, D. G., \& Rasmussen, R. K. (2006). Private Debt and the Missing Lever of Corporate Governance. University of Pennsylvania Law Review, 154, 1209.

4. Baltagi, B. H., Bresson, G., \& Pirotte, A. (2003). Fixed effects, random effects or HausmanTaylor?: A pretest estimator. Economics letters, 79(3), 361-369.

5. Bonin, J., \& Wachtel, P. (2003). Financial sector development in transition economies: Lessons from the first decade. Financial Markets, Institutions \& Instruments, 12(1), 1-66.

6. Burkart, M., \& Ellingsen, T. (2004) In-kind finance: A theory of trade credit. American economic review, 569-590.

7. Byers, S. S., Fields, L. P., \& Fraser, D. R. (2008). Are corporate governance and bank monitoring substitutes: Evidence from the perceived value of bank loans. Journal of Corporate Finance, 14(4), 475-483.

8. Chen, K. C., Chen, Z., \& Wei, K. J. (2009). Legal protection of investors, corporate governance, and the cost of equity capital. Journal of Corporate Finance, 15(3), 273-289.
9. Cheng, B., Ioannou, I., \& Serafeim, G. (2014). Corporate social responsibility and access to finance. Strategic Management Journal, 35(1), 1-23. Retrieved from https://dash.harvard.edu/ bitstream/handle/1/9887635/ cheng,ioannou,serafeim-Corporate\%20Social\%20Responsibility $\% 20$ and $\% 20$ Access $\% 20$ to $\% 20$ Finance.pdf? sequence $=1$

10. Cheng, N. S., \& Pike, R. (2003). The trade credit decision: evidence of UK firms. Managerial and Decision Economics, 24(6-7), 419-438.

11. Cochran, P. L., \& Wood, R. A. (1984). Corporate social responsibility and financial performance. Academy of management Journal, 27(1), 42-56.

12. Cunat, V. (2007). Trade credit: suppliers as debt collectors and insurance providers. Review of Financial Studies, 20(2), 491-527.

13. Demirgüç-Kunt, A., \& Maksimovic, V. (2001). Firms as financial intermediaries: Evidence from trade credit data (Vol. 2696). Citeseer.

14. Du, J., Lu, Y., \& Tao, Z. (2012). Bank loans vs. trade credit. Economics of Transition, 20(3), 457-480. Retrieved from http://onlinelibrary.wiley.com/doi/10.1111/ j.1468-0351.2012.00439.x/full

15. Ferrando, A., \& Mulier, K. (2012). Do firms use the trade credit channel to manage growth? Retrieved from https://www. ecb.europa.eu/pub/pdf/scpwps/ ecbwp1502.pdf?b12bc376092d3b6 cc01745b46bbd98al

16. Fisman, R., \& Love, I. (2003). Trade credit, financial intermediary development, and industry growth. The Journal of Finance, 58(1), 353-374.

17. Florackis, C. (2008). Agency costs and corporate governance mechanisms: evidence for UK firms. International Journal of Managerial Finance, 4(1), 37-59.

18. Ge, W., Kim, J.-B., \& Song, B. Y. (2012). Internal governance, legal institutions and bank loan contracting around the world. Journal of Corporate Finance, 18(3), 413-432. Retrieved from http://www.sciencedirect. com/science/article/pii/ S0929119912000089

19. Ge, Y., \& Qiu, J. (2007). Financial development, bank discrimination and trade credit. Journal of Banking \& Finance, 31(2), 513-530. http://dx.doi.org/10.1016/j.jbankfin.2006.07.009

20. Graff, M. (2003). Financial development and economic growth in corporatist and liberal market economies. Emerging Markets Finance and Trade, 39(2), 47-69.

21. Hill, R. C., Griffiths, W. E., \& Lim, G. C. (2008). Principles of econometrics (Vol. 5). Wiley Hoboken, NJ.

22. Koehn, D., \& Ueng, J. (2005). Evaluating the evaluators: Should investors trust corporate governance metrics ratings? Journal of Management and Governance, 9(2), 111-128.

23. Kwenda, F., \& Holden, M. (2013). Working Capital Structure and Financing Pattern of Selected JSE-Listed Firms. Mediterranean Journal of Social Sciences, 4(13), 531. Retrieved from http://www. 
mcser.org/journal/index.php/ mjss/article/viewFile/1543/1555

24. Kwenda, F., \& Holden, M. (2014). Trade credit in corporate financing in South Africa: evidence from a dynamic panel data analysis. Retrieved from https://www.researchgate.net/ publication/286351762_Trade_ credit_in_corporate_financing_in_ South_Africa_Evidence_from_a_ dynamic_panel_data_analysis

25. Lee, Y. W., \& Stowe, J. D. (1993). Product risk, asymmetric information, and trade credit. Journal of financial and quantitative analysis, 28(02), 285300.

26. Levine, R. (2004). The corporate governance of banks: A concise discussion of concepts and evidence.

27. Mugova, \& Sachs. (2017). Corporate governance and credit financing in a developing economy. Corporate Ownership and Control, 14(4), 341-349. http://doi.org/310.22495/cocv22414i22494

28. Ng, C. K., Smith, J. K., \& Smith, R. L. (1999). Evidence on the determinants of credit terms used in interfirm trade. The Journal of Finance, 54(3), 1109-1129.

29. Nilsen, J. H. (1999). Trade credit and the bank lending channel.

30. Nini, G., Smith, D. C., \& Sufi, A. (2012). Creditor control rights, corporate governance, and firm value. Review of Financial Studies, 25(6), 1713-1761. Retrieved from https://gates.comm.virginia.edu/ dcs8f/CreditorGovernance_WFAsubmission.pdf

31. Petersen, M. A., \& Rajan, R. G. (1994). The benefits of lending relationships: Evidence from small business data. The Journal of Finance, 49(1), 3-37.

32. Petersen, M. A., \& Rajan, R. G. (1997). Trade credit: theories and evidence. Review of Financial Studies, 10(3), 661-691.

33. Rajan, R. G., \& Zingales, L. (1995). What do we know about capital structure? Some evidence from international data. The Journal of Finance, 50(5), 14211460.

34. Sharma, N. (2014). Extent of corporate governance disclosure by banks and finance companies listed on Nepal Stock Exchange. Advances in Accounting, 30(2), 425-439. Retrieved from https://www.researchgate.net/ publication/266749949_Extent_of_corporate_governance disclosure_by_banks_and_finance_companies_listed_on_Nepal_Stock_Exchange

35. Shepherd, J. M., Tung, F., \& Yoon, A. H. (2008). What Else Matters for Corporate Governance: The Case of Bank Monitoring. BUL Rev., 88, 991.
36. Shleifer, A., \& Vishny, R. W. (1997). A survey of corporate governance. The journal of finance, 52(2), 737-783.

37. Skerritt, P. (2009). The financial landscape. Understanding the South African financial markets (3rd ed.). Pretoria: Van Schaik Publishers.

38. Sonnenfeld, J. (2004). Good governance and the misleading myths of bad metrics. The Academy of Management Executive, 18(1), 108-113.

39. Triantis, G. G., \& Daniels, R. J. (1995). The role of debt in interactive corporate governance. California Law Review, 1073-1113.

40. Waddock, S. A., \& Graves, S. B. (1997). The corporate social performance-financial performance link. Strategic Management Journal, 303-319.

41. Williamson, O. E. (1988). Corporate finance and corporate governance. The journal of finance, 43(3), 567-591.

42. Wu, S.-W., Lin, F., \& Wu, C.m. (2014). Corporate social responsibility and cost of capital: An empirical study of the Taiwan stock market. Emerging Markets Finance and Trade, 50(sup1), 107-120. Retrieved from https:// business.illinois.edu/zimmerman/wp-content/uploads/ sites/56/2015/08/046-Feng.pdf 